\title{
Estimates of the natural non-methane VOC emissions from vegetation in Switzerland
}

S. Andreani-Aksoyoglu, J. Keller

Laboratory for Environmental Research and

Systems Analysis, Paul Scherrer Institute,

CH-5232 Villigen PSI, Switzerland

\section{ABSTRACT}

Emissions of biogenic volatile organic compounds (VOC) from forests, agricultural crops and pasture were estimated for Switzerland. Biogenic emissions were found to be about $24 \%$ of the total annual VOC emissions. Calculations showed that the forests are the main sources of the biogenic emissions whereas emissions from crops are only $7 \%$, coming mainly from corn and pasture. The major contribution comes from the coniferous trees, especially from Norway spruce (picea abies) forests due to their abundance and high leaf biomass density. Although broad-leaved forests cover $27 \%$ of all the forests in Switzerland, their contribution to the biogenic emissions is only $2 \%$. Monoterpene emission from the forests is predominantly higher than isoprene emission. Total annual biogenic VOC emission rate of 94 ktonnes $\mathrm{y}^{-1}$ is significantly higher than those from other studies where the forests were classified as deciduous and coniferous. The difference is attributed to the high leaf biomass densities of Norway spruce and fir (abies alba) compared to the other conifers.

\section{INTRODUCTION}

It is now known that neglecting the natural hydrocarbon emissions in air pollution models may lead to inaccurate estimations of pollutant concentrations and to ineffective pollutant reduction strategies based on a reduction of anthropogenic hydrocarbons only. For a realistic strategy to reduce the emission of the predominant air pollutants such as nitrogen oxides $\left(\mathrm{NO}_{\mathrm{x}}\right)$ and 


\section{Pollution Control and Monitoring}

volatile organic compounds (VOC) it is necessary to know the types of the sources as well as their emission rates (all non-methane volatile organic compounds are referred to as VOC throughout this text).

Little is known about the formation of biogenic VOC and thier reaction mechanisms. Despite the wide range of VOC emitted, only isoprene and selected monoterpenes have been extensively studied as emission products from vegetation because of their high reactivity and importance in determining the $\mathrm{OH}$ mixing ratios (Altshuller ${ }^{1}$ ). While both isoprene and terpene emissions are sensitive to temperature, only isoprene emission is strongly affected by the light intensity suggesting to be associated with the photosynthetic activities $\left(\right.$ Tingey $\left.^{2}\right)$. Other factors which have been reported to affect the emission of biogenic VOC are plant age, water deficit and other stresses like air pollution, timber and crop harvesting, death and decay (Hewitt and Street $^{3}$ ). Forests are the primary vegetative source of biogenic emissions and the contribution from the agricultural crops are relatively small compared to those from the forest coverage (Lamb et al. ${ }^{4}$ ). There are relativaly few emission measurements for agricultural crops in the literature (Evans et al. ${ }^{5}$, Winer et al. ${ }^{6}$ ). Although there are some attempts to estimate national biogenic hydrocarbon emissions in various countries (Lamb et al. ${ }^{4}$, Anastasi et al. ${ }^{7}$ ), no detailed study has so far been done in Switzerland. In this paper, estimations on the emission rates of biogenic VOC from vegetation in Switzerland are reported.

\section{METHODOLOGY}

The basic parameters required for developing a biogenic emission inventory are emission factors for the vegetation species, biomass density factors and prevailing conditions such as temperature, light, season, etc. For the forest emission calculations, Switzerland was divided into 5 geographical regions as Jura, Swiss Plateau, Pre-Alpine region, the Alps and the south of the Alps. Biogenic emissions for each region were calculated separately. The calculations were based on the emission rate models of Tingey $^{2}$ and Schürmann ${ }^{8}$. The potential emission of isoprene from Norway spruce was estimated from its $\alpha$-pinene emission rate (Steinbiecher et al. ${ }^{9}$ ). The basic forest types in each region of Switzerland and detailed description of the method are given elsewhere (Andreani-Aksoyoglu and Keller ${ }^{10}$ ). 
For crop and pasture emissions, emission fluxes and compositions were taken from Lamb et al. ${ }^{11}$ (Table I). Agricultural and pasture areas were obtained from the "Schweizerischen Bauernverband" (SBV) ${ }^{12}$. Temperature corrections were made using Tingey's emission rate algorithms for monoterpenes and isoprene. There are some discrepancies in literature about the emission rates measured from corn. Until further measurements are made, the emission rate for corn was assumed to be $2.2 \mu \mathrm{g} \mathrm{g}^{-1} \mathrm{~h}^{-1}$.

TABLE I Biogenic emission data for crops and pasture

\begin{tabular}{|l|c|c|ccc|}
\hline species & $\begin{array}{c}\text { emission flux } \\
\text { at } 30^{\circ} \mathrm{C} \\
\left(\mu \mathrm{g} \mathrm{m}^{-2} \mathrm{~h}^{-1}\right) \\
\left(\mathrm{Lamb} \mathrm{et} \mathrm{al.}^{11}\right)\end{array}$ & $\begin{array}{c}\text { area } \\
\left(10^{6} \mathrm{~m}^{2}\right)\end{array}$ & \multicolumn{3}{|c|}{$\begin{array}{c}\text { \% composition } \\
(\text { Lamb et al. }\end{array}$} \\
\hline corn & 3542 & 648.9 & 0 & 20 & 80 \\
wheat & 30 & 960.7 & 50 & 20 & 30 \\
rye & 39 & 48.2 & 20 & 50 & 30 \\
barley & 37 & 593.5 & 20 & 50 & 30 \\
oat & 38 & 105.4 & 20 & 50 & 30 \\
terpenes & VOC \\
tobacco & 294 & 6.3 & 0 & 20 & 80 \\
potatoes & 48 & 181.0 & 0 & 50 & 50 \\
pasture & 281 & 7293.8 & 20 & 50 & 30 \\
\hline
\end{tabular}

\section{RESULTS AND DISCUSSION}

A large fraction of the Swiss forests (74\%) are coniferous. Among the coniferous trees, Norway spruce (picea abies) is the most abundant one (67\%). Fir (abies alba) is the second important coniferous species (20\%). Scots pine (pinus sylvestris) and the larch (larix decidua, larix kaempferi) cover the rest of the needle-leaved forests in Switzerland. Among the broad-leaved trees, the main species is beech (fagus sylvatica) which covers about $60 \%$ of all the deciduous type trees. The percentages of oak (quercus robur, q. petraea, $q$. 
pubescens, q. cerris, q. rubra), ash (fraxinus excelcior, f. ornus), and Norway maple (acer pseudoplanatus, acer platanoides) are less abundant and are all in the same range (8-9\%). Various studies carried out with oak trees show that the predominant VOC emitted from this species is isoprene (Altshuller ${ }^{1}$ ). However, the area of oak forests in Switzerland is relatively small (2\%). On the other hand, the beech forest which covers about $16 \%$ of the total forest area, and ash, are reported to emit neither isoprene nor terpenes (Hewitt and Street $^{3}$, Steinbrecher et al. ${ }^{13}$ ). The only source for isoprene emission from the deciduous trees is therefore, likely to be the oak forest. In this work, only isoprene and monoterpene emissions from the forests were taken into account. Other VOC cannot be calculated because of the lack of experimental data. The major biogenic VOC emitted by the forests are monoterpenes (97\%) whereas isoprene is only a small fraction of the total emissions. The total annual biogenic VOC emissions from the forests was estimated to be about 87 ktonnes (Andreani-Aksoyoglu and Keller ${ }^{10}$ ). The most substantial biogenic VOC emission $(27 \%)$ is in the region of the Alps where there is the largest Norway spruce forest coverage.

Emission rates of isoprene, monoterpenes and other VOC from the main crops are given in Table II. Emissions from pasture were assumed to take place for all the year whereas emissions from the agricultural land were calculated only for the vegetation period. The contribution of agricultural crops and pasture to the total biogenic emissions is about $7 \%$ and it comes mainly from pasture (54\%) and corn (45\%). Emissions from other crops are negligible. About $38 \%$ of the hydrocarbons are emitted as monoterpenes, $8 \%$ as isoprene and $54 \%$ as other VOC (see Figure 1).

The calculated biogenic VOC emissions account for about $32 \%$ of anthropogenic VOC emissions estimated for the year 1992 (Roesselet and $\mathrm{Kerr}^{14}$ ) and represent $24 \%$ of the total VOC. Comparison of the results with other studies suggests that our estimates for forest emissions are significantly higher than the others (Andreani-Aksoyoglu and Keller ${ }^{10}$ ). The main difference is in the emission from coniferous trees for which our results are about three times higher than those given by BUS ${ }^{15}$. The speciation of coniferous trees by foliage weight in this work, is most probably the reason of this discrepancy. 
TABLE II Emission inventory for crops and pasture

\begin{tabular}{|l|cccc|}
\hline \multirow{2}{*}{ species } & \multicolumn{4}{|c|}{ emission rate (tonnes $\mathrm{y}^{-1}$ ) } \\
& isoprene & monoterpenes & other VOC & total \\
\hline corn & 0 & 614 & 2460 & 3074 \\
wheat & 11.6 & 7.7 & 11.6 & 30.9 \\
rye & 0.3 & 1.3 & 0.8 & 2.4 \\
barley & 3.5 & 14.7 & 8.8 & 27.0 \\
oat & 0.7 & 2.7 & 1.6 & 5.0 \\
tobacco & 0 & 0.5 & 2.0 & 2.5 \\
potatoes & 0 & 5.8 & 5.8 & 11.6 \\
pasture & 535 & 2000 & 1200 & 3735 \\
\hline total & 551 & 2647 & 3691 & 6889 \\
\hline
\end{tabular}

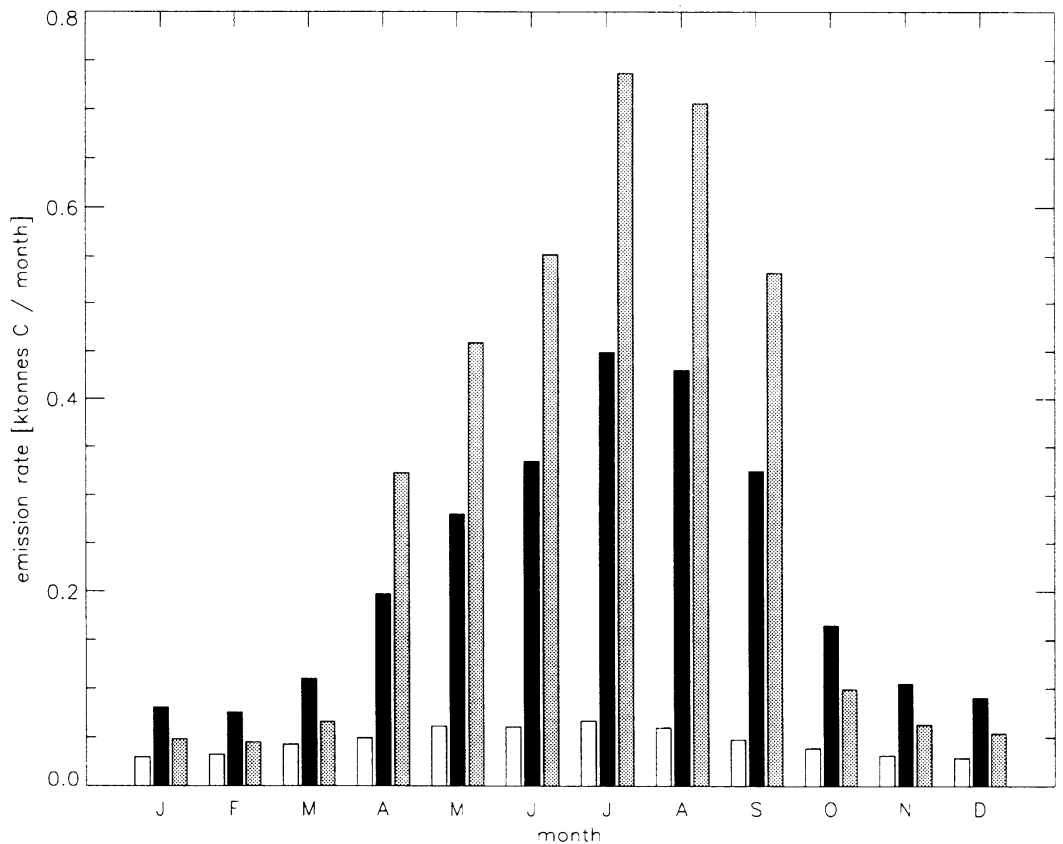

Figure 1 Emission rates for isoprene, monoterpenes and other VOC from crops and pasture in Switzerland 


\section{Pollution Control and Monitoring}

The high foliage weight of Norway spruce accounts for $63 \%$ of the total monoterpene emissions. On the other hand, there is a slight difference in the emission rates for crops and pasture between our results (each about 4 ktonnes VOC $\mathrm{y}^{-1}$ ) and those of BUS ${ }^{15}$ ( 2 and 5.4 ktonnes VOC $\mathrm{y}^{-1}$ respectively) is likely to be due to different emission rates used.

Uncertainties in emission inventories are generally high due to several reasons such as emission rates, land use data and lack of relevant measurements. Assumptions such as spruce type emissions for all kind of spruce trees might lead to inaccurate results, because of the difference in emission types between different picea species (Evans et al. ${ }^{16}$ ). Using the relevant data for Norway spruce which is the most important species in Switzerland for biogenic emissions, uncertainties were tried to be minimized. However, the data obtained from slash pine had to be used for other types of pine trees such as Scots pine, fir and larch. Emissions from these types of trees are supposed to be of pine type, but their emission rate algorithms have not yet been measured. Isoprene emission of Norway spruce is not well known. Although isoprene and monoterpenes are thought to constitute the bulk of the emissions, it has recently become clear that a variety of partially oxidized hydrocarbons are also emitted (Fehsenfeld et al. ${ }^{17}$ ). However, due to the lack of sufficient information, they were not included in this study for forest emissions.

There is considerable uncertainty in the emission rates of agricultural crops. Especially the large discrepancies in the literature about the emission rates measured from corn make the uncertainties high. However, the contribution of crops and pasture to the emissions in Switzerland is small compared to those from the forests. On the other hand, some other areas such as vineyards, fruit and vegetable gardens are not included in this work due to lack of sufficient data. Emissions from them are assumed to be low.

\section{CONCLUSION}

Biogenic VOC emissions from the forests, agricultural crops and pasture in Switzerland were calculated using temperature and light dependent emission rate algorithms. Each tree species known to emit isoprene or monoterpenes was treated individually, using the corresponding emission rate algorithm, leaf 
biomass density, and forest coverage. Calculations carried out using the monthly averaged temperatures over the last ten years showed that emission rate of biogenic VOC is 94 ktonnes $\mathrm{y}^{-1}$ and accounts for $24 \%$ of the total VOC emissions in Switzerland. About $92 \%$ of biogenic VOC emissions come from the forests. Isoprene emitted by the forests is estimated to be only $3 \%$ of all the emissions. The highest biogenic VOC emission (27\%) is in the region of the Alps where there is the largest Norway spruce forest coverage. Norway spruce (picea abies) which covers almost half of the Swiss forests, is the highest VOC emitter in Switzerland (61\%), due to its high biomass density. The second important species is the fir (abies alba), whose emission is about $31 \%$. Emissions from the other species are relatively low. Contribution of crops and pasture to the biogenic VOC emissions is only about $7 \%$ coming mainly from corn and pasture. It was shown that the speciation is very important because of the biomass density factors. Grouping all the coniferous trees together with an average biomass value might lead to underestimated emission values.

\section{ACKNOWLEDGEMENTS}

We would like to thank the Swiss Meteorological Institute (SMA) for providing us with temperature and irradiance data.

\section{REFERENCES}

1. Altshuller A.P. 'Review: Natural volatile organic substances and their effect on air quality in the United States' Atmos. Environ.Vol.17, No.11,pp.21312165,1983

2. Tingey D.T. 'The effect of environmental factors on the emissions of biogenic hydrocarbons from live oak and slash pine' In Atmospheric biogenic hydrocarbons I ed. by Bufalini J.J. and Arnts R.R. Ann Arbor Science, Ann Arbor, MI,1981

3. Hewitt C.N. and Street R.A. 'A qualitative assessment of the emission of non-methane hydrocarbon compounds from the biosphere to the atmosphere in the United Kingdom: Present knowledge and uncertainties' Atmos. Environ. Vol.26A, pp.3069-3077, 1992

4. Lamb B.,Günther A.,Gay D. and Westberg H. 'A national inventory of biogenic hydrocarbon emissions' Atmos. Environ. Vol.21,No.8,pp.1695-1705, 1987

5. Evans R.C., Tingey D.T., Gumpertz M.L.,Burns W.F. 'Estimates of isoprene and monoterpene emission rates in plants' Bot. Gaz. Vol.143, No.3, pp. 304310,1982 
6. Winer A.M., Arey J., Atkinson R., Aschmann S.M., Long W.D., Morrison C.L. and Olszyk D.M. 'Emission rates of organics from vegetation in California's Central Valley' Atmos. Environ., Vol. 26A,pp. 2647-2659, 1992

7. Anastasi C., Hopkinson L. and Simpson V.J. 'Natural hydrocarbon emissions in the United Kingdom' Atmos. Environ. Vol.25A, No.7, pp.1403-1408, 1991

8. Schürmann W. Emission von Monoterpenen aus Nadeln von Picea Abies (L.) Karst. sowie deren Verhalten in der Atmosphäre. Ph.D. Thesis, Technische Universität München, 1993

9. Steinbrecher R., Karbach I., Nitz S. and Ziegler H. 'Isoprene emission from Norway spruce and behavior in the atmosphere of a mature stand' The Proceedings of EUROTRAC Symposium'92. (edited by Borrell P.M. et al.), pp. 293-295, 1993

10. Andreani-Aksoyoglu S. and Keller J. 'Estimates of monoterpene and isoprene emissions from the forests in Switzerland' J. Atm. Chem. (in press), 1994

11. Lamb R., Gay D., Westberg H. and Pierce T. 'A biogenic hydrocarbon emission inventory for the U.S.A. using a simple forest canopy model' Atmos. Environ. Vol.27A, No.11, pp.1673-1690, 1993

12. Statistische Erhebungen und Schaetzungen Sekretariat des Schweizerischen Bauernverbandes (SBV), Brugg, 1992

13. Steinbrecher R., Schürmann W., Schreiner A.M., Ziegler H. 'Terpenoid emissions from common oak (quercus robur L.) and Norway spruce (picea abies L. Karst.)' Proceedings of the CEC/BIATEX Workshop, 4-7 May, 1993, Averio., 1993

14. Roesselet C.M. and Kerr J.A. Photochemical modelling of photo-oxidant levels over the Swiss plateau and emission reduction scenarios. PSI Bericht Nr.93-03, 1993

15. BUS Report, Emissionen von Luftverunreinigenden Stoffen aus natürlichen Quellen in der Schweiz. Schriftenreihe Umweltschutz, Nr. 75, Bundesamt für Umweltschutz (BUS), (since 1988 Bundesamt für Umwelt, Wald und Landwirtschaft, BUWAL) Bern, 1987

16. Evans R.C., Tingey D.T. and Gumpertz M.L. 'Interspecies variation in terpenoid emissions from Engelmann and Sitka spruce seedlings' Forest Sci. Vol.31,pp. 132-142, 1985

17. Fehsenfeld F., Calvert J., Fall R., Goldan P., Guenther A., Hewitt N.C., Lamb B., Liu S., Trainer M., Westberg H., Zimmerman P. 'Emissions of volatile organic compounds from vegetation and the implications for atmospheric chemistry' Global Biogeochemical Cycles, Vol.6, No.4, pp.389430, 1992 